\title{
Assessment of Group of Stone Column under Sesmic Condition
}

\author{
S. D. Futane, A. I. Dhatrak, S. W. Thakare
}

\begin{abstract}
The study of group of stone column is concerned with evaluation and comparison of the behaviour of group of encased stone column and ordinary stone column for static and seismic load condition. Stone column system with specified geometry is modelled and analysed in FEM software program MIDAS GTS 3D. Analysis is categorised into four cases. Pseudostatic method is used for seismic load calculation. The objective of research is to analyse the performance of stone column by considering the effect of various parameters such as diameter of stone column, static and seismic load condition in cohesive clay and silty clay. Effect of encasement is also observed for static loading condition and seismic loading condition. Result shows that encased stone column reduces the settlement and length of stone column.
\end{abstract}

Keywords- Encased stone column, ordinary stone column, static load and seismic load.

\section{INTRODUCTION}

Stone column is a suitable technique of ground improvement for foundations on soft clay. Stone column is a method of soil reinforcement in which soft cohesive soil is replaced by gravel or crushed rock in pre-bored vertical holes to form columns within the soil. Stone column has two basic functions that provide strength, reinforcement to the soil and acts as vertical drains to allow subsoil rapid consolidation under any given load. Stone columns are used to accelerate the rate of consolidation by reducing the length of the drainage path, to reduce the settlement of soft clays and increase the load bearing capacity. It mitigates damage due to the build-up pore pressure, by providing a drainage path and increasing the strength, stiffness of ground and potential for liquefaction. There are two types of stone column installation techniques viz., non-displacement method (rammed stone column) and displacement method (vibro-replacement method). Stone columns are used for the foundations of rail and road embankments, bridge approaches and abutments, offshore bridge abutments, airport runway and taxiways, storage tank (LNG, Crude Oil, LPG etc.) and power plants.

Testing was conducted on stone column to determine performance as liquefaction countermeasure in non-plastic silty soil. Stone columns were effective remediation technique for liquefaction induced settlement of non-plastic silty soil [1].

Revised Manuscript Received on April 04, 2020.

* Correspondence Author

Dr. A. I. Dhatrak*, Associate Professor in Civil Engineering Department, and Dean Academics at Government College of Engineering, Amravati, India.

S. D. Futane , Bachelor's degree in Civil Engineering from Government College of Engineering, Amaravati, India.

S. W. Thakare Associate professor in Department of civil Engineering, Government college of Engineering, Jalgaon, India.

(c) The Authors. Published by Blue Eyes Intelligence Engineering and Sciences Publication (BEIESP). This is an open access article under the CC BY-NC-ND license (http://creativecommons.org/licenses/by-nc-nd/4.0/)
Behaviour of stone column was studied when subjected to cyclic loads installed in marine clay. Settlement was increased with increase in number of cycles [2]. Geosynthetic encased stone columns and ordinary stone columns were installed in kaolinite clay bed to study and behaviour was compared during and after seismic excitation. Experimental setup was subject to large-scale shaking table test to simulate seismic behaviour of columns [3].

\section{METHODOLOGY}

Stone column system with specified geometry was modelled and analysed in FEM software program MIDAS GTS 3D. For the analysis, a 3D model of stone column foundation with a soil block was modelled. The group of stone column embedded in clay was subjected to static and seismic loading condition. Pseudo-static method was used for the calculation of seismic load. Stone columns were designed for actual site condition for analysis purpose, in which one oil tank was considered. Uniformly distributed load was applied by oil tank; therefore analysis was performed on a group of $4 \times 4$ stone columns as shown in Fig.1. Analysis was carried out by varying diameters of stone column. Number of stone columns, spacing and length of stone columns were varied for each diameter. The material properties used for the study are given in Table I.

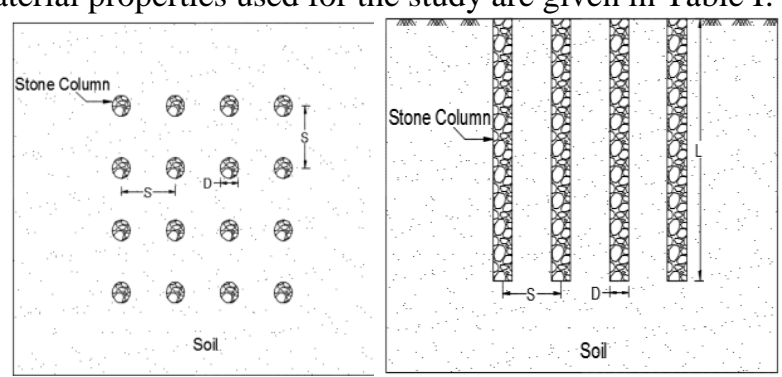

Fig. 1: Typical stone column model with various parameters.

Table I. Material Properties selected for analysis of stone column

\begin{tabular}{|l|c|c|c|c|}
\hline Property & Unit & Soil & $\begin{array}{c}\text { Stone } \\
\text { Column }\end{array}$ & Geogrid \\
\hline Material Model & - & $\begin{array}{c}\text { Mohr- } \\
\text { Columb }\end{array}$ & $\begin{array}{c}\text { Mohr- } \\
\text { Columb }\end{array}$ & Elastic \\
\hline Elastic Modulus & $\mathrm{kPa}$ & 5500 & 55000 & 500000 \\
\hline $\begin{array}{l}\text { Angle } \\
\text { Friction (Ø) }\end{array}$ & degree & - & $43^{-}$ & - \\
\hline Cohesion (c) & $\mathrm{kPa}$ & 30 & - & - \\
\hline $\begin{array}{l}\text { Poisson's Ratio } \\
(\mu)\end{array}$ & - & 0.42 & 0.3 & 0.3 \\
\hline
\end{tabular}

Published By:

Blue Eyes Intelligence Engineering

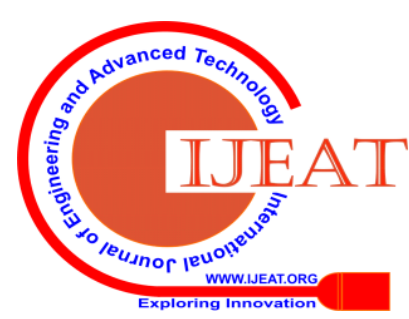




\section{NUMERICAL ANALYSIS}

Analysis was carried out to evaluate settlement of stone column and results were compared for encased stone column and ordinary stone column under static and seismic loading condition. Analysis of group of stone column was divided in four cases:

i. Analyses of stone column for static loading -

Analyses were carried out for stone column group subjected to static loading only.

Table II. Settlement and effect of encasement of stone column for static loading condition in cohesive clay

\begin{tabular}{|c|c|c|c|c|}
\hline $\begin{array}{c}\text { Diameter of } \\
\text { stone } \\
\text { column (m) }\end{array}$ & $\begin{array}{c}\text { Settlement of ordinary } \\
\text { stone column for static } \\
\text { load condition in } \\
\text { cohesive clay (mm) }\end{array}$ & $\begin{array}{c}\text { Settlement of encased } \\
\text { stone column for static } \\
\text { load condition in } \\
\text { cohesive clay (mm) }\end{array}$ & $\begin{array}{c}\text { S.R.R. in } \\
\text { static } \\
\text { loading (\%) }\end{array}$ & $\begin{array}{c}\text { L.R.R. in static } \\
\text { loading (\%) }\end{array}$ \\
\hline 0.6 & 183.11 & 149.90 & 18.13 & 20 \\
\hline 0.8 & 342.01 & 292.29 & 14.53 & 12.85 \\
\hline 1.0 & 460.93 & 401.68 & 26.25 \\
\hline 1.2 & 711.239 & 646.33 & 9.12 & 9.6 \\
\hline
\end{tabular}

loading-

In this case analyses were carried on encased stone column under seismic load condition.

Cohesive soil was used for analysis. Various diameters of stone columns were used viz. $0.6 \mathrm{~m}, 0.8 \mathrm{~m}, 1.0 \mathrm{~m}$ and 1.2 $\mathrm{m}$

\section{RESULTS AND DISCUSSION}

Table III. Settlement and effect of encasement of stone column for seismic loading condition in cohesive clay

\begin{tabular}{|c|c|c|c|c|}
\hline $\begin{array}{c}\text { Diameter of } \\
\text { stone column } \\
(\mathrm{m})\end{array}$ & $\begin{array}{c}\text { Settlement of stone } \\
\text { column for seismic } \\
\text { load condition in } \\
\text { cohesive clay (mm) }\end{array}$ & $\begin{array}{c}\text { Settlement of encased } \\
\text { stone column for } \\
\text { seismic load } \\
\text { condition in cohesive } \\
\text { clay (mm) }\end{array}$ & $\begin{array}{c}\text { S.R.R. in } \\
\text { seismic } \\
\text { loading (\%) }\end{array}$ & $\begin{array}{c}\text { L.R.R. in } \\
\text { seismic } \\
\text { loading (\%) }\end{array}$ \\
\hline 0.6 & 284.88 & 228.60 & 19.75 & 18.94 \\
\hline 0.8 & 543.50 & 440.55 & 23.16 & 24.54 \\
\hline 1.0 & 805.89 & 619.17 & 10.57 & 12.72 \\
\hline 1.2 & 1070.03 & 956.84 & & 12 \\
\hline
\end{tabular}

ratio (L.R.R.) for different diameter of stone column in cohesive clay.

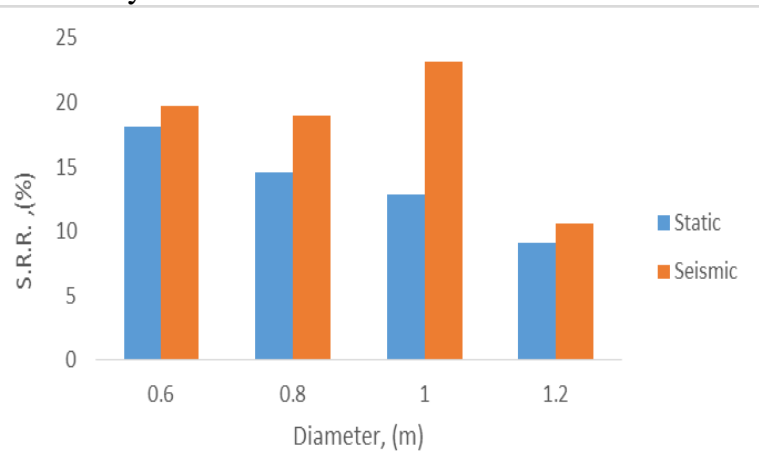

Fig. 2: S.R.R. for different diameter of stone column in cohesive clay ii. Analyses of stone column group for seismic loading Analyses were carried out for the stone column subjected to seismic load by pseudo-static method.

iii. Analyses of encased stone column group for static loading-

In this case analyses were carried on encased stone column under static load.

iv. Analyses of encased stone column group for seismic

Analysis was carried out for $0.6 \mathrm{~m}, 0.8 \mathrm{~m}, 1.0 \mathrm{~m}$ and $1.2 \mathrm{~m}$ diameter of ordinary stone column and encased stone column subjected to static and seismic loading. Settlement obtained from the analysis of group of stone columns and effect of encasement on settlement and length reduction for cohesive clay are given in the table II and table III.

Settlement and length reduction were observed for static loading condition and seismic loading condition due to encasement of stone column. Fig. 2 and Fig. 3 shows settlement reduction ratio (S.R.R.) and length reduction

Table IV shows effect of seismic loading on settlement of stone column in cohesive clay. Settlement was increased due to seismic loading. Percentage increment was determined for stone column without encasement and for encased stone column.

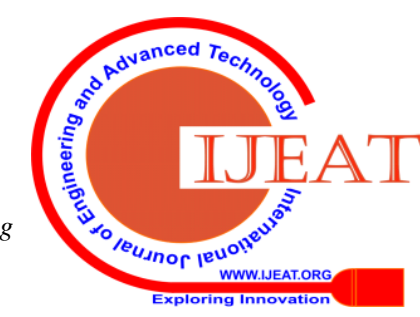




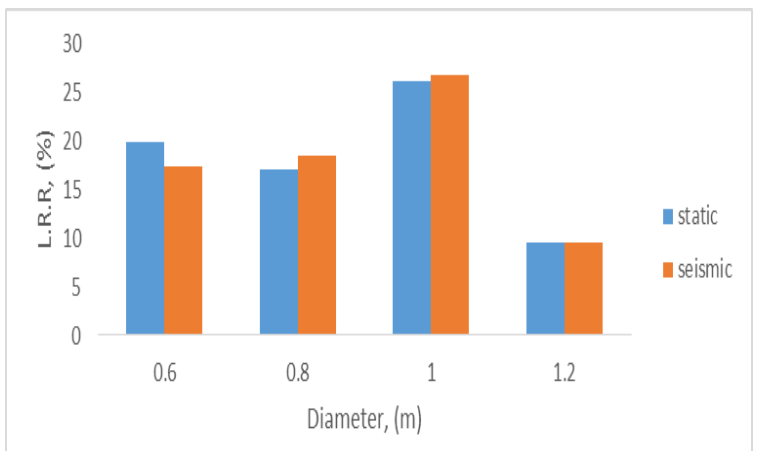

Fig. 3: L.R.R. for different diameter of stone column in cohesive clay
Table IV. Effect of seismic loading on settlement of stone column in cohesive clay

\begin{tabular}{|c|c|c|}
\hline $\begin{array}{c}\text { Diameter } \\
(\mathrm{m})\end{array}$ & $\begin{array}{c}\text { Increment in } \\
\text { settlement of stone } \\
\text { column without } \\
\text { encasement due to } \\
\text { seismic loa ding (\%) }\end{array}$ & $\begin{array}{c}\text { Increment in } \\
\text { settlement of stone } \\
\text { column with } \\
\text { encasement due to } \\
\text { seismic loa ding (\%) }\end{array}$ \\
\hline 0.6 & 55.57 & 52.50 \\
\hline 0.8 & 58.9 & 50.7 \\
\hline 1.0 & 74.83 & 54.14 \\
\hline 1.2 & 50.44 & 48.40 \\
\hline
\end{tabular}

Table V. Settlement and effect of encasement of stone column for static loading condition in silty clay

\begin{tabular}{|c|c|c|c|c|}
\hline $\begin{array}{c}\text { Diameter of } \\
\text { stone column } \\
(\mathrm{m})\end{array}$ & $\begin{array}{c}\text { Settlement of ordinary } \\
\text { stone column for static } \\
\text { load condition in silty } \\
\text { clay (mm) }\end{array}$ & $\begin{array}{c}\text { Settlement of encased } \\
\text { stone column for static } \\
\text { load condition in silty } \\
\text { clay (mm) }\end{array}$ & $\begin{array}{c}\text { S.R.R. in } \\
\text { static loa ding } \\
(\%)\end{array}$ & $\begin{array}{c}\text { L.R.R. in } \\
\text { static loa ding } \\
(\%)\end{array}$ \\
\hline 0.6 & 121.48 & 95.39 & 21.47 & 9.83 \\
\hline 0.8 & 193.16 & 138.49 & 28.30 & 24.54 \\
\hline 1.0 & 268.5 & 199.72 & 25.61 & 10.12 \\
\hline
\end{tabular}

Table VI. Settlement and effect of encasement of stone column for seismic loading condition in silty clay

\begin{tabular}{|c|c|c|c|c|}
\hline $\begin{array}{c}\text { Diameter of } \\
\text { stone column } \\
(\mathrm{m})\end{array}$ & $\begin{array}{c}\text { Settlement of stone } \\
\text { column for seismic load } \\
\text { condition in silty clay } \\
(\mathrm{mm})\end{array}$ & $\begin{array}{c}\text { Settlement of encased } \\
\text { stone column for } \\
\text { seismic load condition } \\
\text { in silty clay (mm) }\end{array}$ & $\begin{array}{c}\text { S.R.R. in } \\
\text { seismic } \\
\text { loa ding (\%) }\end{array}$ & $\begin{array}{c}\text { L.R.R. in } \\
\text { seismic }\end{array}$ \\
\hline 0.6 & 151.85 & 117.77 & 22.44 & 18.94 \\
\hline 0.8 & 252.4 & 188.62 & 23.16 & 24.54 \\
\hline 1.0 & 329.4 & 245.31 & 10.12 & 12.72 \\
\hline
\end{tabular}

Table V and table VI shows settlement obtained from the analyses of group of stone columns and effect of encasement on settlement reduction and length reduction for silty clay. It was observed that, length reduction in static loading condition and seismic loading condition was same in case of silty clay. Fig 4 and 5 shows variation in settlement reduction ratio (S.R.R.) and length reduction ratio (L.R.R.) for different diameter of stone column in silty clay.

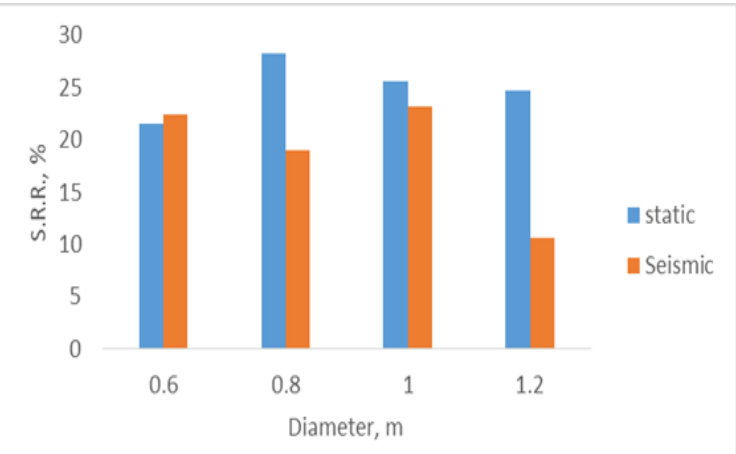

Fig.4: S.R.R. for different diameter of stone column in silty clay
Retrieval Number: D7650049420/2020@BEIESP DOI: 10.35940/ijeat.D7650.049420

Journal Website: www.ijeat.org
Published By:

Blue Eyes Intelligence Engineering

\& Sciences Publication

\& Sciences Publication
(C) Copyright: All rights reserved.

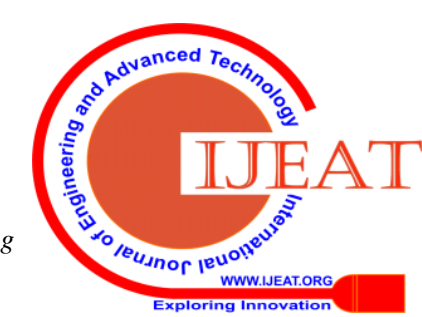




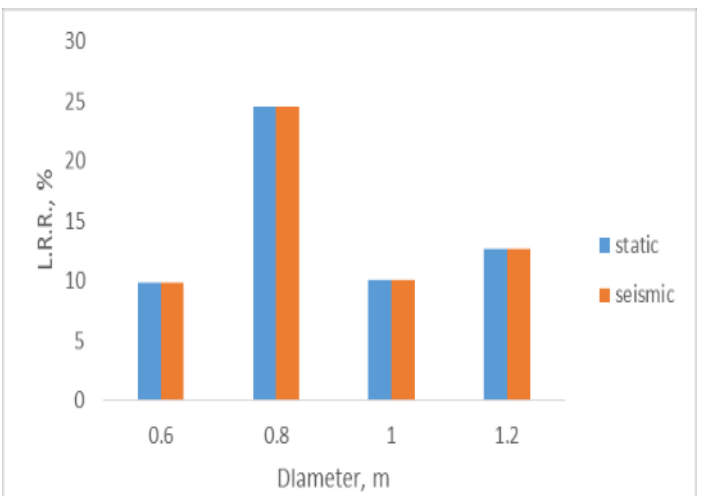

Fig.5:L.R.R. for different diameter of stone column in silty clay

Table VII shows effect of seismic loading on settlement of stone column in silty clay. Increment in settlement of stone column without and with encasement due to seismic loading was calculated.

Table VII. Effect of seismic loading on settlement of stone column in silty clay

\begin{tabular}{|c|c|c|}
\hline $\begin{array}{c}\text { Diameter } \\
(\mathrm{m})\end{array}$ & $\begin{array}{c}\text { Increment in } \\
\text { settlement of stone } \\
\text { column without } \\
\text { encasement due to } \\
\text { seismic loading (\%) }\end{array}$ & $\begin{array}{c}\text { Increment in } \\
\text { settlement of stone } \\
\text { column with } \\
\text { encasement due to } \\
\text { seismic loa ding (\%) }\end{array}$ \\
\hline 0.6 & 25 & 23.46 \\
\hline 0.8 & 30.66 & 36.19 \\
\hline 1.0 & 22.68 & 22.82 \\
\hline 1.2 & 30.29 & 25.76 \\
\hline
\end{tabular}

CONCLUSIONS

A study was conducted using a FE analysis to discuss the effect of static and seismic loading on the ordinary stone column and encased stone column. From this study following conclusions are drawn:

1. Settlement of group of stone column is less in silty clay than cohesive soil.

2. For seismic load, in case of cohesive clay settlement of stone column without encasement found out to be $74 \%$ and settlement of encased stone column is $54 \%$ i.e. encasement of stone column reduces the settlement due to seismic load condition.

3. Settlement of group of stone column is reduced by providing encased stone column. In cohesive clay, settlement of group of stone column for static load condition reduces upto $18 \%$ and for seismic load condition reduces upto $23 \%$.

4. Settlement of group of stone column in silty clay reduces upto $28.30 \%$ in case of static load condition and upto $23.16 \%$ in case of seismic load condition.

5. The length of stone column can be reduced by providing encased stone column. In cohesive clay, length of stone column reduces up to $26.25 \%$ for static load condition and for seismic load condition it reduces up to $26.8 \%$.

6. In case of silty clay length of stone column reduces upto $24.54 \%$ for static as well as seismic load condition.

\section{REFERENCES}

1. K. Adalier, A. Elgamal, J. Meneses, J.I. Baez, "Stone columns as liquefaction countermeasure in non-plastic silty soils." ScienceDirect,ELSEVIER, 2003.

2. Y. Kolekar, O. Shafi Mir, D. Murty, "Behaviour of stone column reinforced marine clay under static and cyclic loading." Indian geotechnical conference H-133, 2011.

3. C. Cengiz, E. Güler, "Seismic behavior of geosynthetic encased columns and ordinary stone columns." ScienceDirect, ELSEVIER, 2018.

4. L. Tang, S. Cong, X. Ling, J. Lu, A. Elgama, "Numerical study on ground improvement for liquefaction mitigation using stone columns encased with geosynthetics." ScienceDirect ,ELSEVIER, 2015

5. R. Ziaie Moayed, A. Mahigir, "Circular Raft Footings Strengthened by Stone Columns under Dynamic Harmonic Loads."World Academy of Science, Engineering and Technology International Journal of Geotechnical and Geological Engineering Vol: 12, No: 1, 2018.

6. IS 15284 (part 1): 2003 Code of practice for design and construction for ground improvement - Guidelines, part 1stone column

7. Z. Ben Salem, W. Frikha and M. Bouassida, "Effects of Densification and Stiffening on Liquefaction Risk of Reinforced Soil by Stone Columns." International Journal of Geomechnics, ASCE GT.1943-5606.0001773, 2017.

8. A. P. Ambily, and S. R. Gandhi, "Behavior of Stone Columns Based on Experimental and FEM Analysis." International Journal of Geomechnics, ASCE.1090-0241(2007)133:4(405), 2007.

\section{AUTHOURS PROFILE}

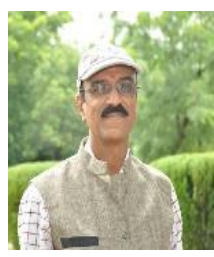

Dr. A. I. Dhatrak is working as Associate Professor in Civil Engineering Department, and Dean Academics at Government College of Engineering, Amravati, India. With thirty-one year of experience, he has completed his Ph.D. in 2014. He has more than 90 publications in national and international journal and conferences. He has guided more than 40 students in their PostGraduation dissertation in geotechnical Engineering. Currently he is guiding six Ph.D. student and thirteen master students in geotechnical engineering.

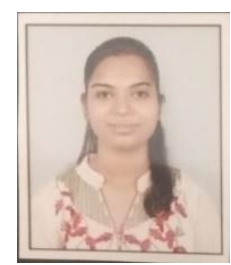

S. D. Futane has completed her Bachelor's degree in Civil Engineering from Government College of Engineering, Amaravati, India. Currently she is pursuing her Master Degree in Geotechnical Engineering at Government College of Engineering, Amaravati, India.

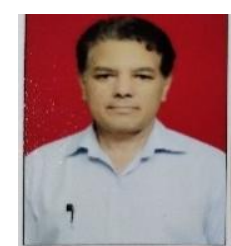

S. W. Thakare is working as Associate professor in Department of civil Engineering, Government college of Engineering, Jalgaon, India. Currently with thirty-two years of experience, he is pursuing his Ph.D. in "Evaluation of capacities of Barrette Pile Foundation in Sandy soil" at Government college of Engineering, Amravati, India. He has published 40 research paper in various national and international journals and conferences. He has guided about 40 students for their Post-Graduation dissertation in Geotechnical Engineering.

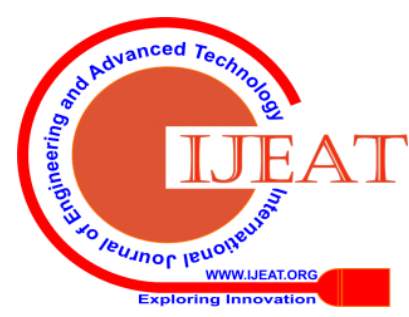

